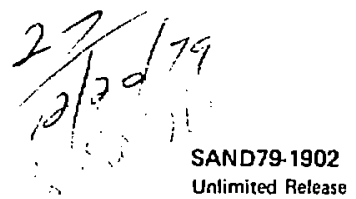

\title{
Instrumentation Development for the Waste isolation Pilot Plant (WIPP) Borehole Plugging Program (BHP)
}

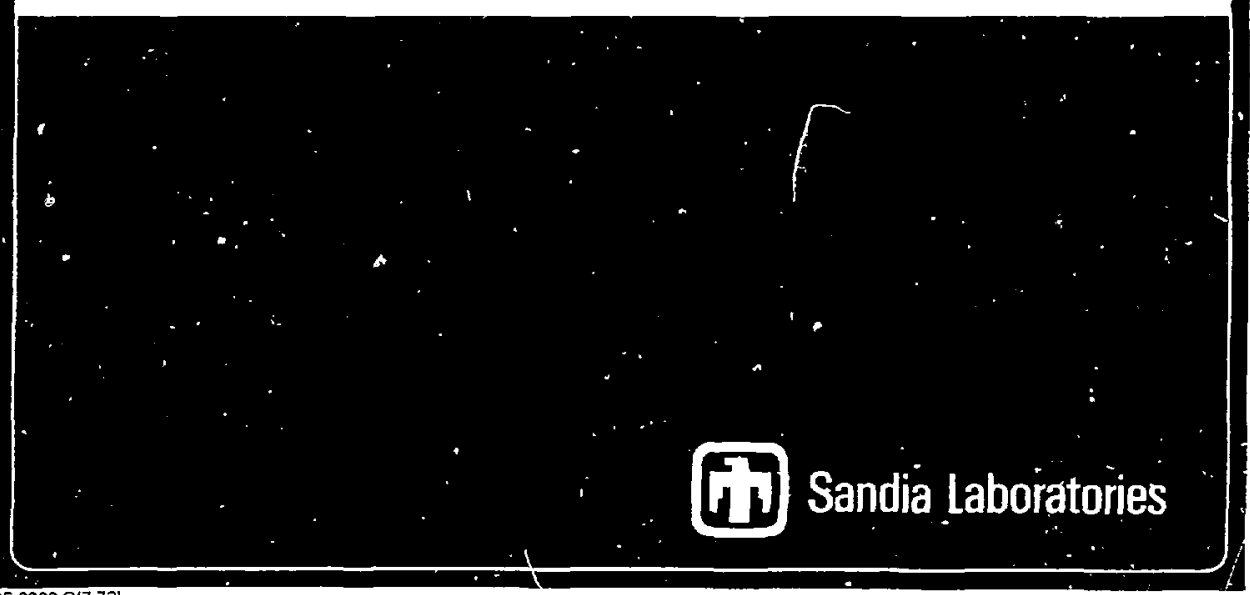


SAND 79-1902

Unlimited Release

Publisher November 1979

INSTRUMENTATION DEVELOPMENT FOR THE

WASTE ISOLATION PILOT PLAN'T (WIPP) BOREHOLE PLUGGING PROGRAM (BHP)

C. Wayne cook

Experiments Division 1116

Sandia Laboratories

Albuquerque, NM B7185

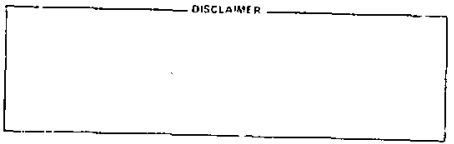

ABSTRACT

This report discusses the instrunentation development needs of the borehole testing program as $i$ it now exists. Although recuirements may change as the program progresses, the items indicated are basic to any borehoie plugglng program. Instrumentation is discussed both for the plug environment and for the plug itself. For the plug environment, a probe for measuring the disturbed region and a coordinate logging tool are requirso. For the plug icself, instrumentation includes measuretents above, within, and below the plug. Instrumentation Eor most measurements above the plug is curcently avilible; for measurements within and below the ?lug, however, further development is required. Speciflcally, resistlvity, induction, and acoustic probes; $\exists n$ in situ stressmeter; and a hardwire, feedthrough system need to ne developed. 
TABLE OF CONTENTS

Page

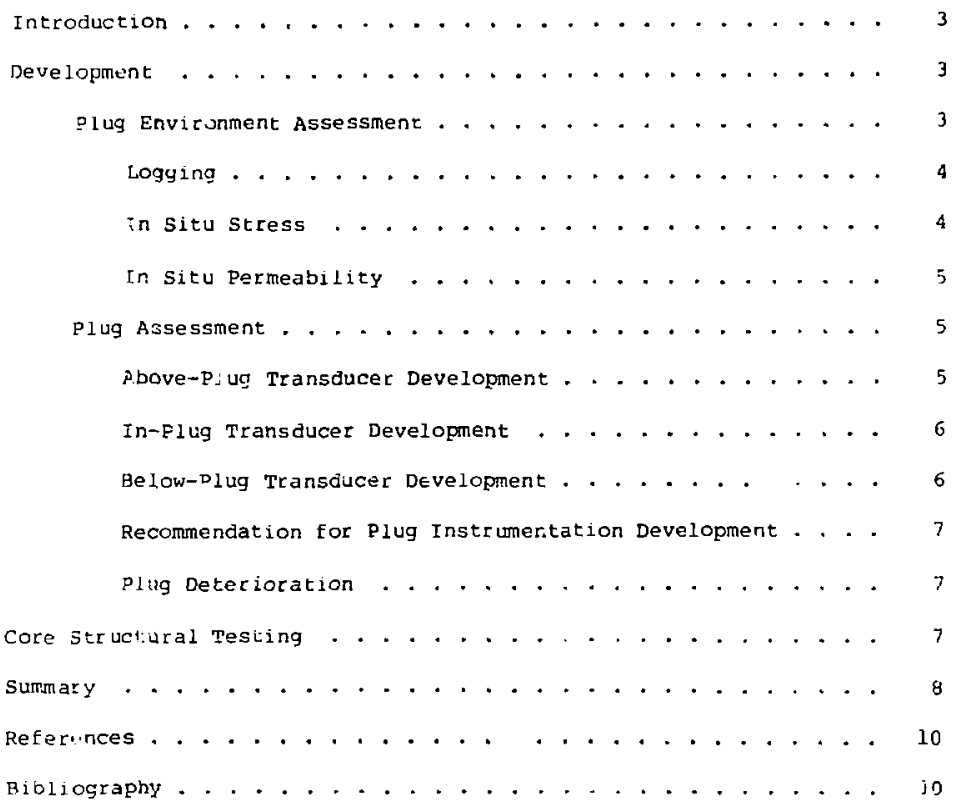




\section{INSTRUMENTATION DEVELOPMENT FOR TIE \\ WASTE ISOLATION PILOT PLANT (WIPP) BOREHOLE PLUGGING (BHP) PROGRAM}

\section{Introduction}

One objective addressed by the WIPP BHP Program description document ${ }^{1}$ is to develop materials, techniques, and instrumentation for determining the adequacy of plug designs in keeping well-bore leakage comparatle to leakage along natural migration pathways.

To achieve this objective, instrumentation that provides data for the assessment of any borehole environment and the validation of plugging techniques is required. Before plug emplacement, borehole conditions and the properties of the surrounding media need to be determined. After emplacement, the integrity and performance of the plug need to be certified. This report presents an instrumentation development plan to provide the required data based on needs identified by the BHP document. The primary emphasis is on instrumentation to acquire data from emplaced cementitious plugs rather than from laboratory tests. Laboratory testing of plugging techniques will be complementary and parallel.

The instrumentation development plan assesses both tre existing borehole environment (which characterizes the borehole and the properties of the host rock) and borehole plug in place perfornance.

Development $\mathrm{P}$ !an

\section{Plug Environment Assessment}

The borehole plug environment to be defined includes both the actual borehole chatacterization and the properties of the host rock. Borehole characterization encompasses a determination of the surface condition of the wall as well as the degree and extent of tha disturbance caused by drilling. hole conditioning, and preparation. The host rock needs to be characterized in terms of thermomechanical and geochemical properties and permeability. To provide a baseline, the host-rock properties should be those of the least-disturbed in situ material. 
Instrimentation to characterize the borehole environment can be defined in the general-use assessment categories of logging, in situ stress, and in situ perncability.

Logging--State-of-the-art logging techniques can the uszd for most of the borehole characterization and evaluation. As part of the environment characterization, core samples will be taken and cataloged from the areas of interest. The one area in which existing logging equipment may not be adequate is that of measuring the disturbed region around the borehole.

Development of logging tools is required to determine the extent of the disturbed region of a borehole. The most iikely techniques for these measurements are ecoustic and/or electromagnetic probes. The possiblity of minlaturizing probes to a 50-mm diameter will be pursued during the develoftent of scanning probes that can penetrate geologic formations. Current long-range planning suggests that some boreholes may be plugged with an open-center plug. With this type plug, scanning probes may prove useful for evaluating plug deterioration and the plug-to-wall bond, as wel as the disturbed region.

In experiments with satellite hcles, it is important to determine the coordinates of all measurement. locations. A logging tool that accurately locates measurement conrdinates is needed to operate in holes with diameters between 70 and $210 \mathrm{mri}$ and at depths of 5 to $1500 \mathrm{~m}$.

In Sicu Stress--The modification of the local stress field by drilling and subsequent relaxation of the borehole needs to be determined. An approximation of the Eracturing and increased permeability caused by stress relief cas be asceriained through modeling. Any restoration of the stress field ard subsequent. hezling may require monitoring after plug emplacement.

Sandia has developed extensometers and inclusion stressmeters ${ }^{2}$ that can be applied to shallow holes $(-20 \mathrm{~m}$ deep). These instruments may be placed in either the main borehole or in nearby satellite holes. 
Further development of this instrumentation wlll be required for deep holes. A first step in this evaluation is to spply existing technology in test holes $\sim 15 \mathrm{~m}$ deep that are locater in a mine. Following successful completion of this phase, modiftcations for deep-hole applications should be developed. Acoustic techniques may also provide a nondestructive test for in situ stress.

In Situ Permeability--A measurement of the permeability of the host rock is required to determine the minimum permeability requirement for the borehole plug.

Currently the experience of systems, science, and software $\left(5^{3}\right)$ is being used in this area. $s^{3}$ uses tracer-gas/pressurization techniques to assess the porosity and permeability of geological media. More detais on the techniques used can be found in Reference 3. Further developmene of in situ permeability instrumentation is planned.

\section{Plug Assessment}

The purpose of a borehole plug is to minimize the transport of fluids through the borehole. The emplaced plug is adequate if the pormeability of the plug and the plug/host interface is less than that of the in situ host rock. If this iceal condition cannot be acilieved, any departures can be determined by measurement. A consequence analysis from these data is necessary to determine the adequacy of the plug. Further, the integrity and performance of emplaced plugs may need to be monitored for long periods to detect any deterioration or changes. Plug deterioration could result in loss of mechanical properties (strength, bond to host rock, etc) and/or an increase in permeability,

Above-Plug Transducer Development--Instrumentation prohes developed for the Bell Canyon Test (BCT) ${ }^{4}$ essentially satisfy the requirement for above-the-plug measurements. Sandia has developed a probe for measuring water level, and conductivity, pressire, and temperature abor:- a borehole plug. ${ }^{5}$ The conductivity probe provides a rough 
measure of d:ssolvea salts that can be useful in ident:fyz.ag the source of the water. $\mathrm{S}^{3}$ also devised for the $\mathrm{BCT}$ a method of measuring permeability through the plugged region that uses time-released tracer gases. The BCT will decermine if turther instrumentation developitent is reguired cor future tests.

In-Plug Transducer Development--When plugs with thicknesses greater than a few metres re installed, measurements have to be made within the plug. Sandia has started the development of two probes that can be grouced in plave to monitor tha leakage of brine past the plug. These twn protes, a Wenner resistivity probe and a monccoil inductance probe, will be available in 1980. The Wenner probe uses a mi-itole-probe azcay to probe varying volumes that inciude the plug, 1 mizeface, and region outside the plug. A prototype model of this probe nas untergone preliminary laboratory tests. The monocoil inductance probe is a tackup epproach that $1 \mathrm{~s}$ also intended so renitor brine leakage past the plig. The primary advantage of the inductancs 0011 is that it does not require good electrical contact with the plug material. Both probes wili require further laboratory evaluations before they can be fielded.

Dther transduce.; that may prove useful within the plug are an inclusion stressmeter and an acoustic probe. The stressmeter woula monitor loading changes on the plug, ard the acoustic probe would detect changes in the integrıt: of the plug.

Bejow-Plug Transducer Development--The transmlssion system for transducer data from below the borehole plug will be investigated to determine whether to use wireless or hardwire methods. Hardwire systems will jo evaluated and tested to determine if methods can be developed to overcome the inherent disadvantages of this method (leakage paths through the plug, cable breakage, and environment-induced deterioration). The short-term potential of this method appears greater than that of a wireless transmission system. wireless transmission ${ }^{6}$ will be investigated to determine if adaptation is acrievable for this application. The long-term serviceability of electronics components used by this system is considered to be unpredicrable.? 
Because of the costs of development and evaluation and the potential problems of the two systems, the hardwire system is the prime candidate for this application.

Recommendations for Plug Instrumentation Development--In-PIug. Development and evaluation of the Wenner and inductance probes should be completed. Studies using the inclusion stressmeter and acoustic probes should also be initiated.

Below-plug. Laboratory tests need to be cun to develop cable feed through technology. Past underground test experience at the Nevada Test site can serve as a starting point. It needs to be established that a hardwire feedthrough is not the weak link in an emplaced plug. Once this has been done, hardwice systems should be developed for use in and below emplaced plugs.

Plug Deterioration--Plug deterioration will be determined indicectly by observing changes in leakage rate or permeability using the instrumentation recommended in the preceding section. The reason for plug detericration will have to be determined from laboratory $z:=t s$ of plug samples.

\section{Core Structural Testing}

Laboratory structural tests of various grout mixtures are typisally run using grout core samples. It is desirable to run some of these tests on full-size plugs in rock samples, with the actual downhole enviconment (confining pressure and temperature) simulated. Other Eull-scale plug tests may also be needed. It appears that some full-scale laboratory tests can probably be run in the large test facility at the University of California, Berkeley. This facility is currently being used on an ONWI contract. 8 
SUMMARY

The instrumentation development discussed in the preceding sections resulted from the needs of the isorehole testing program as it now exist5. Instrumentation requirements will probably change as the program progresses, but the items indicated are fairly basic to any Lrehole plugging program. For conciseness, the instrumentation deveiopment plan is sumarized in Table 1. 
Table 1

Surnary of Instrumentation Development Plan

\begin{tabular}{|c|c|c|c|}
\hline Item & $\begin{array}{c}\text { Design } \\
\text { Responsibility }\end{array}$ & Design Phase & $\begin{array}{l}\text { Ready for } \\
\text { Eielding } \\
\end{array}$ \\
\hline $\begin{array}{l}\text { water level and } \\
\text { conductivity }\end{array}$ & SLA & complete & now \\
\hline tracer (gas) & 53 & complete & now \\
\hline resistivity probe & SLA & $10 / 78$ & $3 / 80$ \\
\hline induction probe & SLA & $10 / 78$ & $3 / 80$ \\
\hline in situ stress & SLA & comple te & $\begin{array}{c}\text { now (shallow } \\
\text { hole) }\end{array}$ \\
\hline hardwire feed-thru & SLA & $8 / 79$ & $6 / 80$ \\
\hline $\begin{array}{l}\text { disturbed region } \\
\text { probe }\end{array}$ & $\begin{array}{l}\text { to be } \\
\text { decided }\end{array}$ & & \\
\hline $\begin{array}{l}\text { coordinate logging } \\
\text { tool }\end{array}$ & $\begin{array}{l}\text { to be } \\
\text { decided }\end{array}$ & & \\
\hline acoustic in-plug probe & $\begin{array}{l}\text { to be } \\
\text { decided }\end{array}$ & & \\
\hline $\begin{array}{l}\text { full-scale plug } \\
\text { test }\end{array}$ & $\begin{array}{l}\text { to be } \\
\text { decided }\end{array}$ & & \\
\hline
\end{tabular}


References

1. C. [. Christensen, and T. O. Hunter, Waste Isolation Pilot Plant (WIPP) Borehole plugging program Description January 1, 1979, SAND79-0640, (Albuquerque: Sandia Laboratories, August 1979).

2. C. W. Cook, and E. S. Ames, "Borchole-Inclusion Stressmeter Measurements in Bedded Salt," 20th U S Symposium on Rock Mechanics, Austin. Texas, June 1979, pp 431-489.

3. E. W. Peterson, and P. L, Lagus, "In Situ Characterization of Permeability, Porosity and Communication in Underground Regions," Systems, Science, and Software, June 1977.

4. C. L, Christensen, Test Plan, Bell Canyon Test, WIPP Experimental Progrim. Borehole plugging, SAND79-0739, (Albuquerque: Sandia Laboratories, June 1979).

5. C. W. Cook, Instrumentaton for the Bell Canyon Borehole plugginc Test, (Albuquerque: Sandia Laboratories, to be published).

6. J. Stokes, R. Galloway, and D. Swift, Development of a Sensor system for Monitoring Borehole Plugs, I - Selection of the Sensor for the Experimental Prototype Borehole Plug Monitor, Interim Report, IRT0055-006, (Instrumentation Research Technology (IRT), July 1978).

7. D'Appolonia Consulting Engineers, Inc.. The Status of Borehole Plugging and Shaft Sealing for Geologis Isolation of Radioactive Waste, Report No. ONWI15 (D'Appoliona, January 1979).

B. D. Watkins, University of California at Berkeley, private communication.

$$
\text { Binl:ography }
$$

1. Westinghouse Electric Corporation, Advanced Energy Systems Division, $\underline{A}$ Systems Analysis of Instrumentation for In-Situ Examination of Rock Properties, ORNL Document $\sharp Y / O W I / S U B-76 / 99096$, Dctober 1976.

2. C. M, Koplik, D. L. Pentz, ard R. Talbot, Information Base for Waste Repository Design, Volume I - Borehole and Shaft Sealingr NUREG/CR-0495, TR-1210-I (Nuciear Regulatory Commission. Aarch 1979). 